Article

\title{
Advantages of Applying Large-Scale Energy Storage for Load-Generation Balancing
}

\author{
Dawid Chudy * (D) and Adam Leśniak (1D \\ Institute of Electrical Power Engineering, Lodz University of Technology, Stefanowskiego Str. 18/22, \\ PL 90-924 Lodz, Poland; adam.lesniak@dokt.p.lodz.pl \\ * Correspondence: dawid.chudy@dokt.p.lodz.pl
}

check for

updates

Citation: Chudy, D.; Leśniak, A. Advantages of Applying Large-Scale Energy Storage for Load-Generation Balancing. Energies 2021, 14, 3093. https://doi.org/10.3390/en14113093

Academic Editor: Egwu Eric Kalu

Received: 9 March 2021

Accepted: 21 May 2021

Published: 26 May 2021

Publisher's Note: MDPI stays neutral with regard to jurisdictional claims in published maps and institutional affiliations.

Copyright: (C) 2021 by the authors. Licensee MDPI, Basel, Switzerland. This article is an open access article distributed under the terms and conditions of the Creative Commons Attribution (CC BY) license (https:// creativecommons.org/licenses/by/ $4.0 /)$.

\begin{abstract}
The continuous development of energy storage (ES) technologies and their wider utilization in modern power systems are becoming more and more visible. ES is used for a variety of applications ranging from price arbitrage, voltage and frequency regulation, reserves provision, black-starting and renewable energy sources (RESs), supporting load-generation balancing. The cost of ES technologies remains high; nevertheless, future decreases are expected. As the most profitable and technically effective solutions are continuously sought, this article presents the results of the analyses which through the created unit commitment and dispatch optimization model examines the use of ES as support for load-generation balancing. The performed simulations based on various scenarios show a possibility to reduce the number of starting-up centrally dispatched generating units (CDGUs) required to satisfy the electricity demand, which results in the facilitation of load-generation balancing for transmission system operators (TSOs). The barriers that should be encountered to improving the proposed use of ES were also identified. The presented solution may be suitable for further development of renewables and, in light of strict climate and energy policies, may lead to lower utilization of large-scale power generating units required to maintain proper operation of power systems.
\end{abstract}

Keywords: load-generation balancing; large-scale energy storage; power system services modeling; power system operation; power system optimization

\section{Introduction}

Nowadays, the cost of most energy storage (ES) technologies remains high, making it impossible to ensure return on investment for many grid applications [1]. This claim applies, inter alia, to battery technologies [2-4]. The profitability of a given technology and application is also dependent on additional factors, such as specific market conditions and installation site [5]. On the one hand, only the most profitable and technically effective solutions are currently chosen by new investors, but on the other, further reduction of ES costs can increase their profitability and scope of application [6-8]. It is therefore expected that new ways of ES exploiting will emerge shortly.

The most popular applications of ES in the power system include price arbitrage, voltage and frequency regulation, reserves provision, black-starting, renewable energy sources (RESs) supporting and load-generation balancing $[9,10]$. The use of ES for grid balancing was analysed mainly in the scope of distribution networks (medium voltage (MV) and low voltage (LV) networks). The battery ES intended to provide balancing services at MV distribution feeder was presented, inter alia, in [11,12]. The ES technologies may also perform balancing services compensating renewables energy fluctuations, as shown in $[13,14]$. The current research covered multiple services which combine balancing with reactive power compensation [15] and power loss minimization [16]. Illustrative applications in LV networks cover the balancing performed by centrally located and dispersed ES [17], services performed by multiple ES cooperating with smart buildings [18], 
and residential photovoltaic (PV) installations [19]. A high potential is also demonstrated by vehicle-to-grid (V2G) technologies and utilization of reused vehicle batteries which lead to better performance of renewables, reducing their curtailment and better utilizing excess energy [20-22].

To the best knowledge of the authors, only a little attention has been paid to the balancing services performed by large-scale ES which allow not only for the compensation of load-generation fluctuations but also for the reduction of the number of starting-up centrally dispatched generating units (CDGUs) required to satisfy the peak electricity consumption. Consequently, the remainder of the article will focus on this particular ES application.

The best opportunities to provide load-balancing services by the ES appear during significant, fast changes in electricity demand. In many power systems, such fast changes occur in the morning, such as in the example presented in Figure 1, where demand may change by about $30 \%$ over a few hours $[23,24]$.

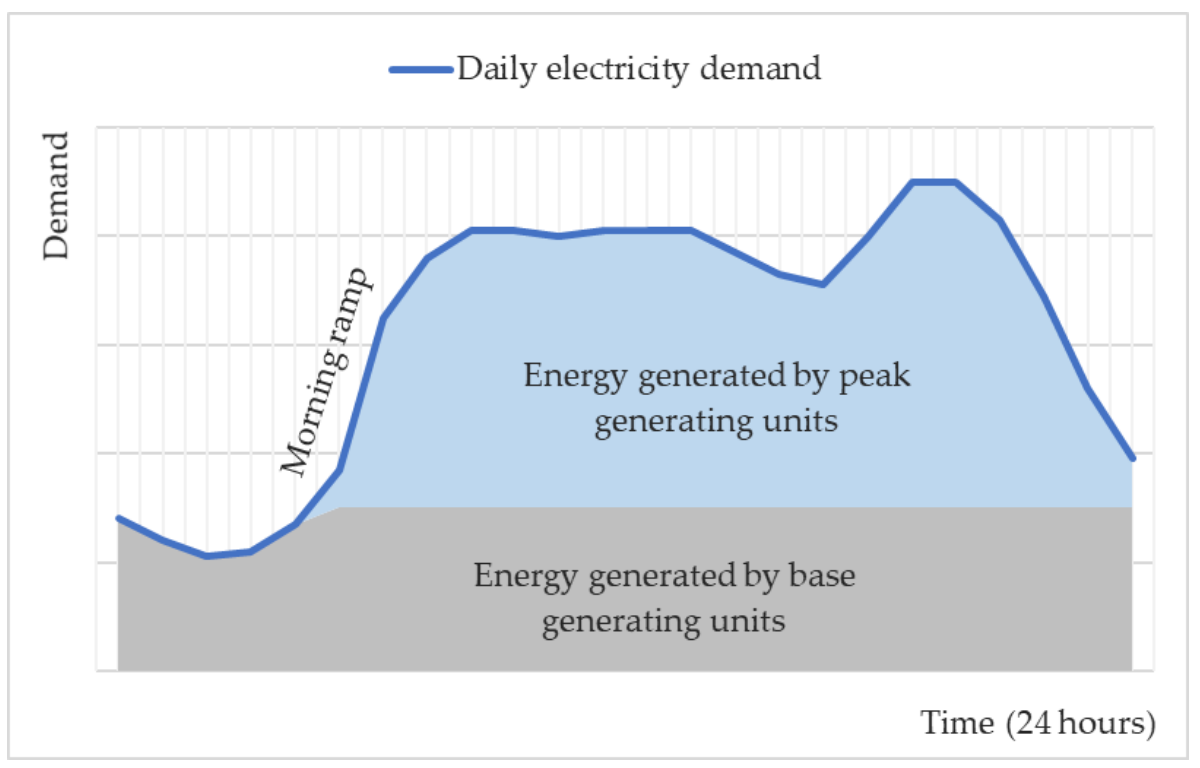

Figure 1. An example of the daily electricity demand and the operation of base and peak generating units. Own development based on [25].

The fast-growing demand is satisfied by starting-up peak power generating units. The peak units have higher costs and, unlike baseload generation, adjust their output power in a greater scope as a response to changes in the electricity demand.

The starting-up generating unit injects fixed portions of energy to the power grid following its start-up characteristic, as presented in Figure 2. The fixed course of the characteristic is related to the warming-up processes of plant installations and machinery. During the start-up, a given unit cannot be controlled and does not take active participation in the load-generation balancing. The start-up of a power generating unit lasts until the unit reaches its required minimum output power, and from that point it can be controlled by the power system operator [26]. 


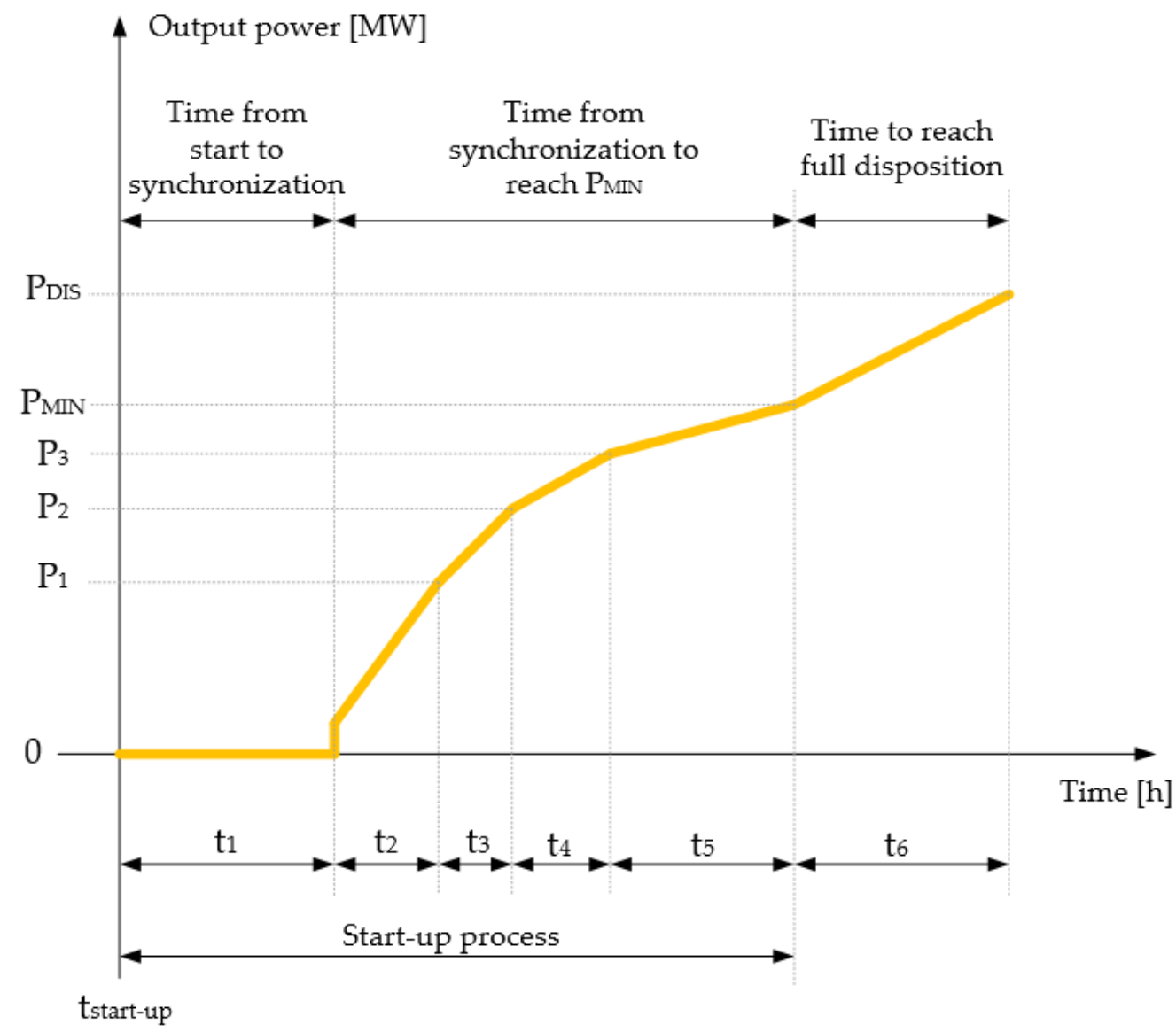

Figure 2. An example of the start-up characteristic, where: tstart-up-the time point when the startup begins; $\mathrm{t}_{1}-\mathrm{t}_{6}$-characteristic times related to the warming up processes; $\mathrm{P}_{1}-\mathrm{P}_{3}$-characteristic values of output power related to the warming up processes; PMIN_minimum technical output power after start-up process; PDIS—-minimum output power available for the system operator taking into account power reserved for the provision of the additional services. Own development based on $[26,27]$.

During the morning ramp of demand, many generating units perform start-ups and do not provide load-generation balancing services. Such a situation is dangerous from the perspective of the power system, as unpredictable changes in demand and emergencies constitute a risk for the stability of the system operation. The growing number of start-ups is also associated with higher overall costs of the power system operation as more expensive units are committed into production [23,24]. Additionally, the starting-up CDGUs require the usage of more expensive heavy fuels, such as mazuts. The limitation of starting-up power generating units required to satisfy the daily electricity demand can be therefore very desirable; nevertheless, the majority of currently performed research does not examine the advantages of reducing the number of CDGU start-ups.

The utilization of ES for load-generation balancing, taking into account the number of CDGU start-ups, has been described, e.g., in $[23,24]$. The author presented the mixedinteger linear programming (MILP) optimization model with an objective function aimed at the reduction of CDGU start-ups and shut-downs. The simulations performed for different shares of ES in the modeled system present the first insight into the analysed problem. In [28], the use of unit commitment and dispatch models are incorporated; nevertheless, the simulations assume a fixed number of CDGU start-ups during the simulation horizon and are intended only to show general patterns of large-scale ES operation. A concept assuming the replacement of combined cycle gas turbines (CCGTs) operating during peaks of demand by large-scale ES is presented in [29]. The results indicate a significant impact on 
the limitation of CCGT operation and carbon dioxide $\left(\mathrm{CO}_{2}\right)$ reductions; nevertheless, the idea cannot be applied for other types of CDGUs as specific fixed start-up characteristics were not considered. The authors of [30] assumed dedicated large-scale ES charged by wind power plant output energy. The presented approach resulted in the reduction of peak-load CDGUs, but the outcome depends on the wind/storage ratio. Another approach is presented in [31] where the limitation of start-ups, taking into account coal-based units, is performed by distributed assets located in the MV network as a positive consequence of the load profile smoothing services.

A novel approach presented within this article constitutes a development of the previously published works. Firstly, it shows the utilization of large-scale ES for the balancing purposes on the transmission grid level, oppositely to concepts presented in [11-22] where considered ES are located in distribution systems (LV and MV networks). Subsequently, an improved MILP unit commitment and dispatch model based on [28,32-35] is introduced. The model allows for analyses of different simulation scenarios, thus various operation patterns and parameters of ES can be implemented. Additionally, the model can be easily reproduced. Thirdly, the performed simulations show the specific operation of ES reducing the number of CDGU start-ups and facilitating load-generation balancing. The additional barriers in further service provision are also identified. The presented work increases the scope and the application of the findings presented in $[23,24,29,30]$. Finally, the conclusions of the article indicate the future field of studies related to restrictions imposed by climate and energy policies and cost-benefit analyses.

The remainder of the paper is organized as follows: the second section presents the developed unit commitment and dispatch simulation model. Section 3 describes the main assumptions and simulation scenarios. Section 4 discusses the results of the simulations, while the last section concludes the article.

\section{Simulation Model}

The core of the presented MILP unit commitment and dispatch simulation model is based on the methodology presented in [28,32-35]. The model reflects a transmission system that includes large-scale power generating units (CDGUs), large-scale ES, non-dispatchable generation (renewables, combined heat and power (CHP), import and industry) and loads. The copper plate interpretation of the power grid is implemented assuming a lack of constraints and unlimited energy transmission between connected entities. Further simulation horizon reflects $24 \mathrm{~h}$ with 1-h intervals.

\subsection{Power Generating Units}

Centrally dispatched large-scale power generating units constitute the majority of the generating assets in the modeled system and assume the main responsibility for loadgeneration balancing. Two types of CDGUs can be distinguished: base-load and peak-load. The first have lower operational costs and change their output power only in a limited range, while the latter have higher costs, change their output power in a greater scope and start up and shut down in a response to significant demand changes.

For the whole simulation horizon $\mathrm{T}$, the output power $\mathrm{p}_{\mathrm{G} \text { out }}(\mathrm{g}, \mathrm{t})$ of all CDGUs $\mathrm{G}$ has to be limited within their lower and upper limits denoted respectively as $P_{G \text { min }}(\mathrm{g})$ and $\mathrm{P}_{\mathrm{G} \text { max }}(\mathrm{g})$. Binary variables bin $_{\mathrm{G}}(\mathrm{g}, \mathrm{t})$ reflect $\mathrm{ON}$ and $\mathrm{OFF}$ states of a generating unit (Equation (1)) [32,33].

$$
\forall \mathrm{g} \in \mathrm{G}, \forall \mathrm{t} \in \mathrm{T}: \mathrm{P}_{\mathrm{G} \min }(\mathrm{g}) \cdot \operatorname{bin}_{\mathrm{G}}(\mathrm{g}, \mathrm{t}) \leq \mathrm{P}_{\mathrm{G} \text { out }}(\mathrm{g}, \mathrm{t}) \leq \mathrm{P}_{\mathrm{G} \max }(\mathrm{g}) \cdot \mathrm{bin}_{\mathrm{G}}(\mathrm{g}, \mathrm{t})
$$

The possible variations in the output power $\mathrm{p}_{\mathrm{G} \text { out }}(\mathrm{g}, \mathrm{t})$ are constrained by an increase (ramp-up) and decrease (ramp-down) limits, denoted respectively as $r_{u}(g)$ and $r_{d}(g)$ (Equation (2)) [32,33].

$$
\forall \mathrm{g} \in \mathrm{G}, \forall \mathrm{t} \in[2 . .24]: \mathrm{p}_{\mathrm{G} \text { out }}(\mathrm{g}, \mathrm{t}-1)-\mathrm{r}_{\mathrm{d}}(\mathrm{g}) \leq \mathrm{p}_{\mathrm{G} \text { out }}(\mathrm{g}, \mathrm{t}) \leq \mathrm{p}_{\mathrm{G} \text { out }}(\mathrm{g}, \mathrm{t}-1)+\mathrm{r}_{\mathrm{u}}(\mathrm{g})
$$


The peak load CDGUs are committed into production when periods of higher consumption occur. As mentioned before, during their start-ups CDGUs have to follow the fixed characteristic related to warming-up processes of installations and machinery. An assumed start-up pattern is shown in Figure 3.

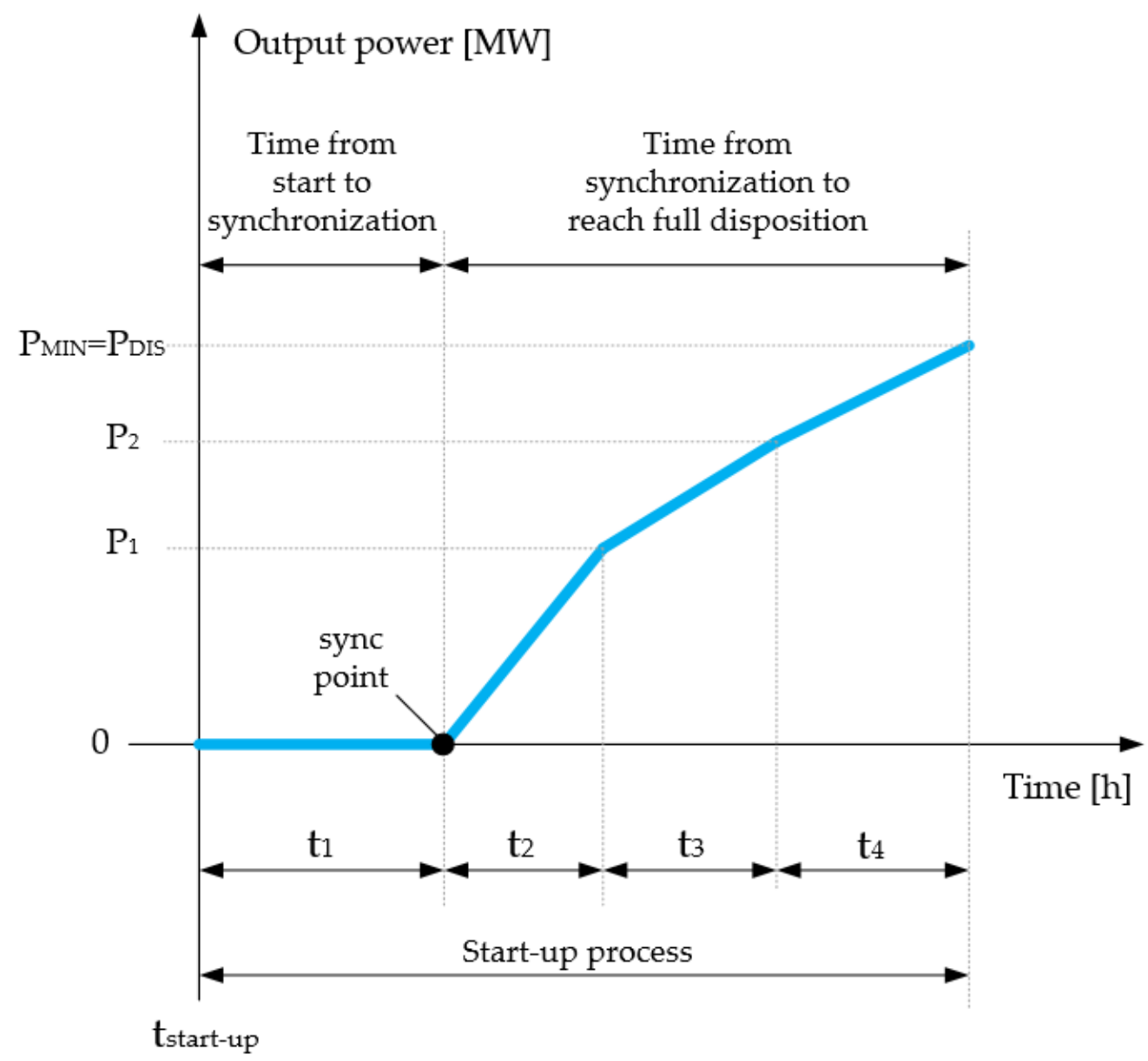

Figure 3. The assumed start-up characteristic of power generating units, where: tstart-up-the time when the start-up begins; $t_{1}-t_{4}$-characteristic times related to the warming up processes; $\mathrm{P}_{1}-\mathrm{P}_{2}-$ characteristic values of output power related to the warming up processes; PMIN = PDIS-minimum output power of a given power generating unit. Own development based on [26-28].

To satisfy the increased demand, it is necessary to activate subsequent peak-load CDGUs. The synchronization of a unit starts after time $t_{1}$ from the beginning of the start-up $\left(t_{\text {start-up }}\right)$. In the presented model the signal for the synchronization sync $(\mathrm{g}, \mathrm{t})$ of a given CDGU $g$ is determined by the binary variables $\operatorname{bin}_{G}(g, t)$ responsible for its OFF and ON states (Equation (3)). Additionally, variable sync (g,t) is limited to be positive or zero (Equation (4)).

$$
\begin{gathered}
\forall \mathrm{g} \in \mathrm{G}, \forall \mathrm{t} \in[2 . .24]: \operatorname{sync}(\mathrm{g}, \mathrm{t}) \geq \operatorname{bin}_{\mathrm{G}}(\mathrm{g}, \mathrm{t})-\operatorname{bin}_{\mathrm{G}}(\mathrm{g}, \mathrm{t}-1) \\
\forall \mathrm{g} \in \mathrm{G}, \forall \mathrm{t} \in[2 . .24]: \text { sync }(\mathrm{g}, \mathrm{t}) \geq 0
\end{gathered}
$$

The sync $(\mathrm{g}, \mathrm{t})$ variable is used to count the total sum of start-ups ( sum $_{\text {start-up }}$ ) during the simulation period (Equation (5)). This sum is used in the following part of the paper to depict the results that show the impact of energy storage on the operation of CDGUs (Section 4).

$$
\text { sum }_{\text {start-up }}=\sum_{\mathrm{t}=1}^{\mathrm{T}}\left[\sum_{\mathrm{g}=1}^{\mathrm{G}} \text { sync }(\mathrm{g}, \mathrm{t})\right]
$$


After the synchronization, a given CDGU begins to inject its output energy into the power system. During the initial phase the amount of energy is consistent with the start-up characteristic (Figure 3). From the moment of reaching the output power equal to PMIN = PDIS, a unit is operating according to its optimal pattern or it is modified to provide ancillary services (ASs) depending on the requirements of the power system operator. The model assumes that CDGUs do not provide any additional services during the simulations.

\subsection{Energy Storage}

Large-scale ES, thanks to its bulk parameters and fast response time, can provide a load-generation balancing service next to the CDGUs.

The chosen ES model described in [34,35], by specifying required parameters, allows for the implementation of any type of ES. Equation (6) presents the minimum ( $\left.\mathrm{E}_{\mathrm{ES}} \mathrm{min}\right)$ and

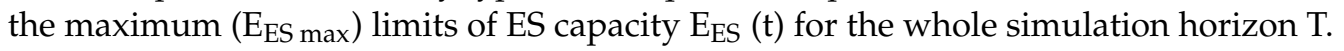

$$
\forall \mathrm{t} \in \mathrm{T}: \mathrm{E}_{\mathrm{ES} \min } \leq \mathrm{E}_{\mathrm{ES}}(\mathrm{t}) \leq \mathrm{E}_{\mathrm{ES} \max }
$$

Operating power constraints (Equations (7) and (8)) reflects maximum charge power $\left(\mathrm{P}_{\mathrm{ES}}\right.$ char max $)$ and maximum discharge power $\left(\mathrm{P}_{\mathrm{ES} \text { dischar max }}\right)$ of ES. They also contain binary

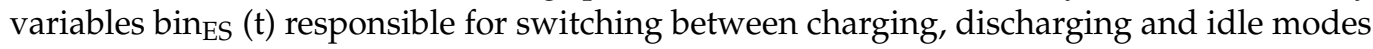
of ES.

$$
\begin{aligned}
& \forall \mathrm{t} \in \mathrm{T}: \mathrm{P}_{\mathrm{ES} \text { char }}(\mathrm{t}) \leq \operatorname{bin}_{\mathrm{ES}}(\mathrm{t}) \cdot \mathrm{P}_{\mathrm{ES} \text { char max }} \\
& \forall \mathrm{t} \in \mathrm{T}: \mathrm{P}_{\mathrm{ES} \text { dischar }}(\mathrm{t}) \leq\left(1-\operatorname{bin}_{\mathrm{ES}}(\mathrm{t})\right) \cdot \mathrm{P}_{\mathrm{ES} \text { dischar max }}
\end{aligned}
$$

Modeled ES maintains energy $\mathrm{E}_{\mathrm{ES}}(\mathrm{t})$ through charge and discharge cycles according to Equation 9 . The charge cycle is defined by charge power $\mathrm{P}_{\mathrm{ES} \text { char }}(\mathrm{t})$, charge time $\mathrm{t}_{\mathrm{ES}}$ char

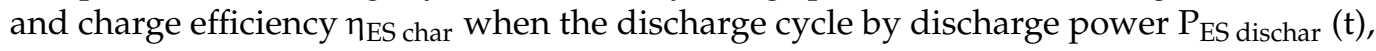
discharge time $t_{\mathrm{ES}}$ dischar and discharge efficiency $\eta_{\mathrm{ES} \text { dischar }}$.

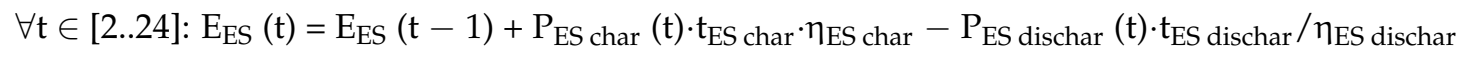

\subsection{Non-Dispatchable Generation and Loads}

Non-dispatchable generation cannot be controlled by the system operator and therefore does not take part in load-generation balancing. It covers renewables, $\mathrm{CHP}$, import and industry and is modeled by a fixed profile.

The presented analysis focuses on the large-scale ES, and therefore all loads are assumed to be passive. The demand to be covered by all power generating units is also modeled by a fixed pattern.

The assumed fixed profiles related to the non-dispatchable generation and loads are presented in the following section (Section 3).

\subsection{Global Constraint}

A global constraint given by Equation (10) ensures that the total demand Dem ( $t$ ) and the energy required for ES charging $\left(\mathrm{E}_{\mathrm{ES}}\right.$ char $\left.(\mathrm{t})\right)$ are balanced with total generation consisting of the energy generated by all CDGUs $G\left(E_{\text {out }}(g, t)\right)$, energy injected by startingup CDGUs after synchronization $\left(\mathrm{E}_{\text {start-up }}(\mathrm{g}, \mathrm{t})\right)$, energy discharged by $\mathrm{ES}\left(\mathrm{E}_{\mathrm{ES} \text { dischar }}(\mathrm{t})\right)$ and output energy from all non-dispatchable assets $\left(E_{\text {non-dis }}(t)\right)[28]$.

$\forall \mathrm{t} \in \mathrm{T}:$ Dem $(\mathrm{t})+\mathrm{E}_{\mathrm{ES} \text { char }}(\mathrm{t})=\sum_{\mathrm{g}=1}{ }^{\mathrm{G}}\left(\mathrm{E}_{\text {out }}(\mathrm{g}, \mathrm{t})+\mathrm{E}_{\text {start-up }}(\mathrm{g}, \mathrm{t})\right)+\mathrm{E}_{\mathrm{ES} \text { dischar }}(\mathrm{t})+\mathrm{E}_{\text {non-dis }}(\mathrm{t})$

\subsection{Objective Functions}

The objective function reflects the unit commitment and dispatch aimed at minimization of the overall costs of the power system operation. In the first step of further simulations, the load-generation balancing is provided only by CDGUs and the objective 
function is given by Equation (11). The costs of CDGUs are represented by the cost of energy injected into the power system during their normal operation $\left(\mathrm{C}_{\mathrm{G}}(\mathrm{g}, \mathrm{t})\right)$ and during start-ups $\left(\mathrm{C}_{\mathrm{SU}}(\mathrm{g}, \mathrm{t})\right)$.

$$
o b j=\min \left\{\sum_{t=1}^{T}\left[\sum_{g=1}^{G}\left(C_{G}(g, t)+C_{S U}(g, t)\right)\right]\right\}
$$

In the subsequent simulations ES also takes part in load-generation balancing, therefore the objective function takes into account ES costs $\left(\mathrm{C}_{\mathrm{ES}}(\mathrm{t})\right)$ related to the accumulation and transformation of the energy which is further injected by them into the modeled system and is expressed as follows (Equation (12):

$$
\mathrm{obj}=\min \left\{\sum_{\mathrm{t}=1}^{\mathrm{T}}\left[\sum_{\mathrm{g}=1}^{\mathrm{G}}\left(\mathrm{C}_{\mathrm{G}}(\mathrm{g}, \mathrm{t})+\mathrm{C}_{\mathrm{SU}}(\mathrm{g}, \mathrm{t})\right)+\mathrm{C}_{\mathrm{ES}}(\mathrm{t})\right]\right\}
$$

\section{Assumptions}

\subsection{Electricity Demand}

The simulation model adopts the power system created to satisfy an electricity demand with peak consumption equal to about $22 \mathrm{GW}$. The assumed load (demand) profile is presented in Figure 4.

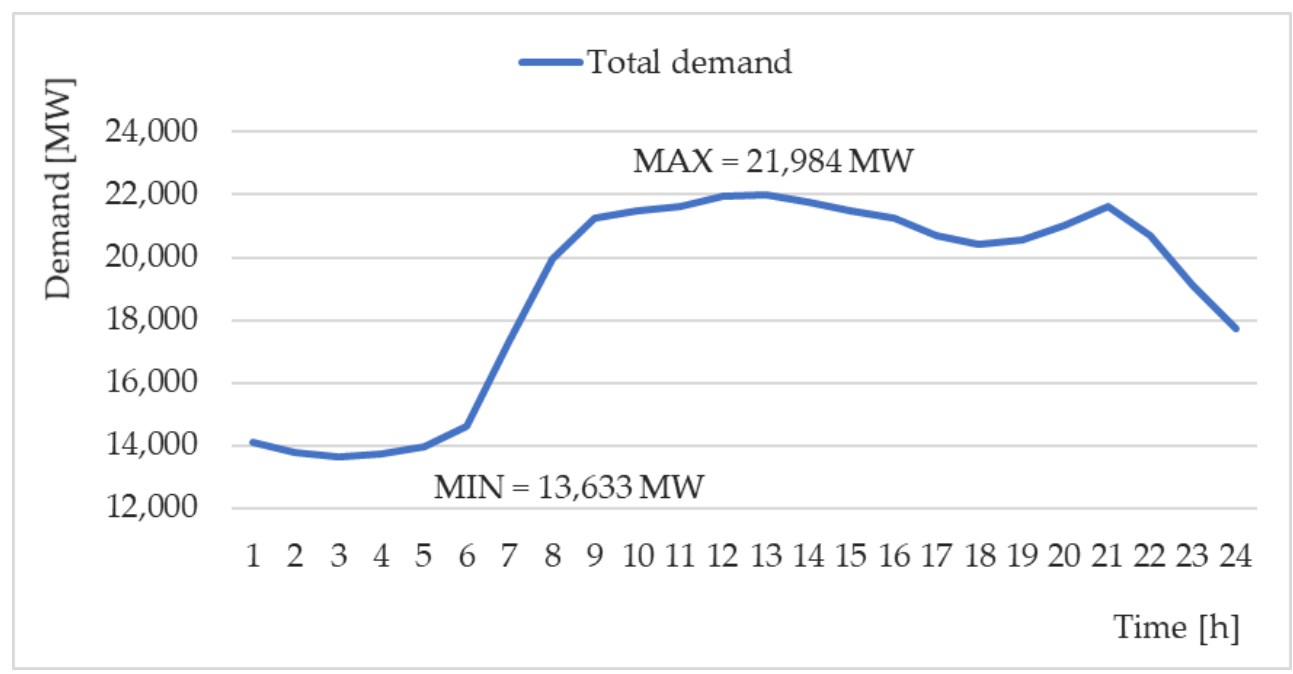

Figure 4. The assumed fixed load (demand) profile. Data source [25].

The assumed demand profile represents an exemplary daily load from the operation of the real power system [25]. Despite other analyses in the literature that take into account the annual profile because they focus on economic assessments, only a one-day load profile was adopted in the paper. The choice of this representative day was considered and motivated by the significant change in the demand during the morning hours visible in Figure 4. The load covers the whole considered system.

The non-dispatchable generation, such as renewables, CHP, import and industry, also takes part in the covering of the total demand. Their assumed fixed profile is presented in Figure 5.

Due to the fixed character of the non-dispatchable generation, further optimization covers only the demand to be satisfied by CDGUs (the electricity consumption to be covered by non-renewable generation was deducted from the total demand profile). The resulting profile is denoted as the remaining demand and presented in Figure 6. 


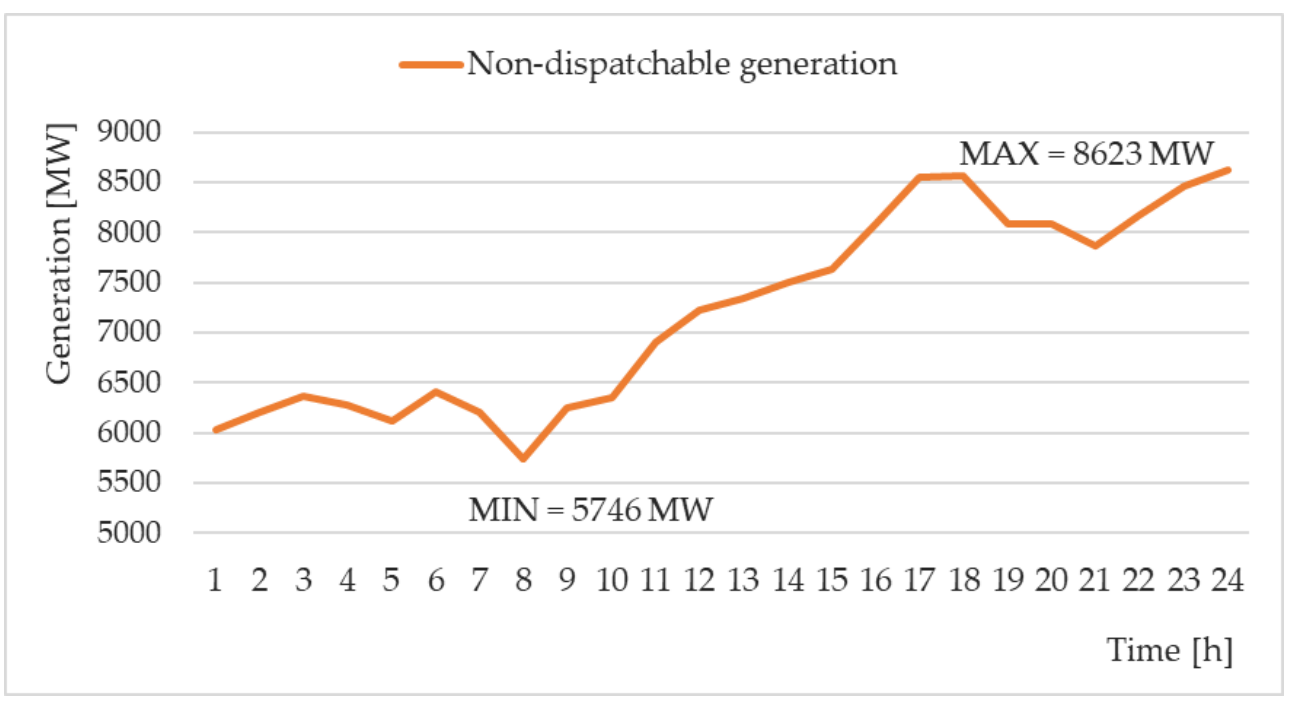

Figure 5. The assumed fixed profile of non-dispatchable generation. Data source [36].

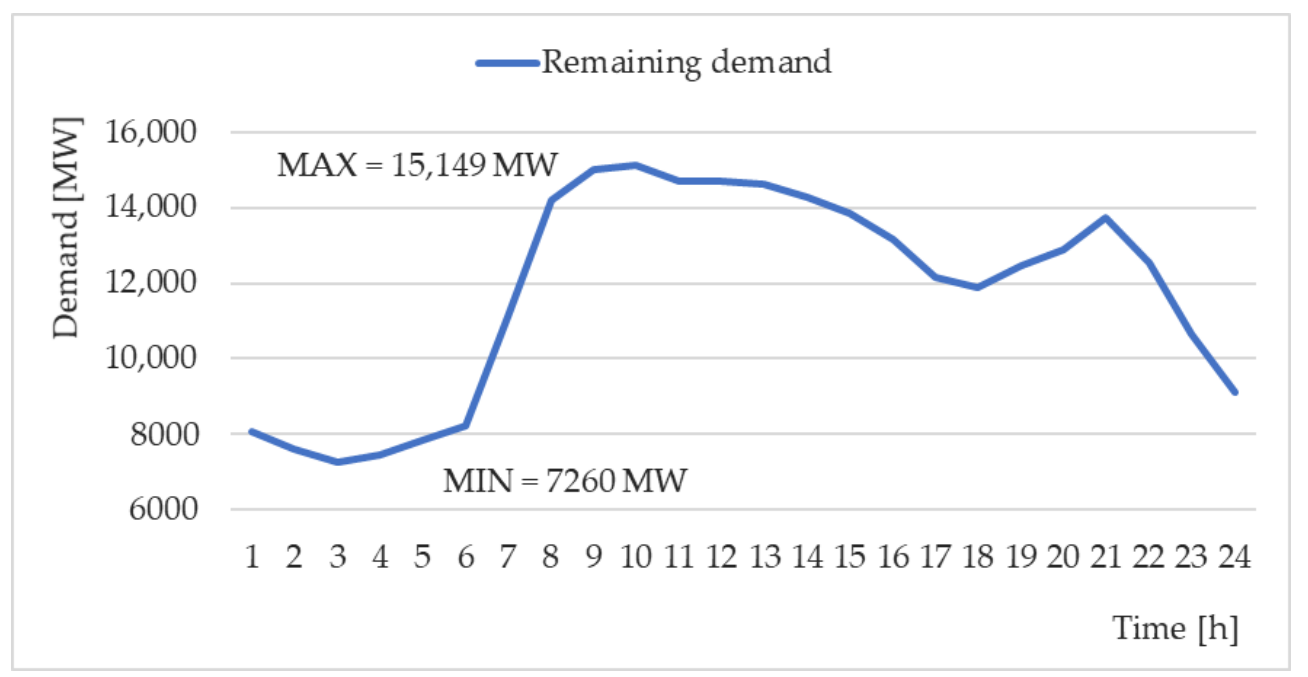

Figure 6. The remaining demand profile assumed for further simulations.

\subsection{Power Generating Units}

The load-generation balancing of the modeled power system is based on 45 CDGUs differentiated according to technical parameters and operating costs. The main technical and economic parameters are presented in Table 1.

Table 1. Parameters of the model-centrally dispatch power generating units (CDGUs). Cost parameters based on [27,37].

\begin{tabular}{lllllll}
\hline $\begin{array}{l}\text { Number } \\
\text { of Units }\end{array}$ & $\begin{array}{l}\text { Rated } \\
\text { Output } \\
\text { Power }\end{array}$ & $\begin{array}{l}\text { Minimum } \\
\text { Output } \\
\text { Power }\end{array}$ & $\begin{array}{l}\text { Maximum } \\
\text { Ramp }\end{array}$ & Type & $\begin{array}{l}\text { Operating } \\
\text { Costs/MWh }\end{array}$ & $\begin{array}{l}\text { Start-Up } \\
\text { Costs/MWh }\end{array}$ \\
\hline 25 & $200 \mathrm{MW}$ & $80 \mathrm{MW}$ & $120 \mathrm{MW} / \mathrm{h}$ & Peak-load & $\begin{array}{l}\text { High } \\
(100 \%)\end{array}$ & $\begin{array}{l}\text { High } \\
(160 \%)\end{array}$ \\
15 & $400 \mathrm{MW}$ & $160 \mathrm{MW}$ & $200 \mathrm{MW} / \mathrm{h}$ & Base-load 1 & $\begin{array}{l}\text { Medium } \\
(60 \%)\end{array}$ & - \\
5 & $1000 \mathrm{MW}$ & $400 \mathrm{MW}$ & $200 \mathrm{MW} / \mathrm{h}$ & Base-load 2 & Low $(30 \%)$ & - \\
\hline
\end{tabular}

Operating costs / MWh cover the overall costs of electricity production by a given type of unit. The peak-load generating units are characterized by the highest costs, denoted as 
$100 \%$, which also constitutes the reference for costs of other CDGUs and ES. For base-load units generating costs are lower and are equal respectively to $60 \%$ and $30 \%$ of the peakload generating costs. Start-up costs/MWh are borne by peak-load units committed into production during periods of high electricity consumption. Those costs are equal to $160 \%$ of normal operating costs due to the specific character of start-up processes described in previous sections.

Table 2 presents parameters related to the assumed start-up characteristic presented previously in Figure 3.

Table 2. Parameters of the modelled start-up characteristic.

\begin{tabular}{ll}
\hline Parameter & Value \\
\hline Output power $\mathrm{P}_{1}$ & 0.5 PMIN [MW] \\
Output power $\mathrm{P}_{2}$ & 0.7 PMIN [MW] \\
Output power PMIN & According to Table 1 [MW] \\
Time interval $\mathrm{t}_{1}$ & $2 \mathrm{~h}$ \\
Time interval $\mathrm{t}_{2}$ & $1 \mathrm{~h}$ \\
Time interval $\mathrm{t}_{3}$ & $1 \mathrm{~h}$ \\
Time interval $\mathrm{t}_{4}$ & $1 \mathrm{~h}$ \\
\hline
\end{tabular}

\subsection{Energy Storage}

The parameters of the ES are related to the further simulation scenarios and will be specified in the following subsection. For all ES, the round-trip efficiency is assumed at $81 \%$ ( $90 \%$ charge efficiency and $90 \%$ discharge efficiency) and operating costs/MWh as $140 \%$ of peak-load generating costs [38]. The assumed parameters can be modified according to the chosen ES technology.

\subsection{Simulation Scenarios}

The simulation scenarios assume different shares of ES in the modeled power system to analyse their impact on the power system operation, especially in terms of the limitation of the number of CDGU start-ups. The set of the main simulation scenarios is presented in Table 3.

Table 3. Description of the main simulation scenarios, where ES-energy storage.

\begin{tabular}{ll}
\hline Scenario & Description \\
\hline Reference scenario & No ES operation \\
Scenario 1 & ES: $250 \mathrm{MW} / 750 \mathrm{MWh}$ \\
Scenario 2 & ES: $500 \mathrm{MW} / 1500 \mathrm{MWh}$ \\
Scenario 3 & ES: $1000 \mathrm{MW} / 3000 \mathrm{MWh}$ \\
Scenario 4 & ES: $2000 \mathrm{MW} / 6000 \mathrm{MWh}$ \\
\hline
\end{tabular}




\section{Simulation and Results}

The graphical presentation of the simulations' results covers the fulfillment of the demand by the different generating units and the ES (Figure 7) and energy stored in the ES (Figure 8).
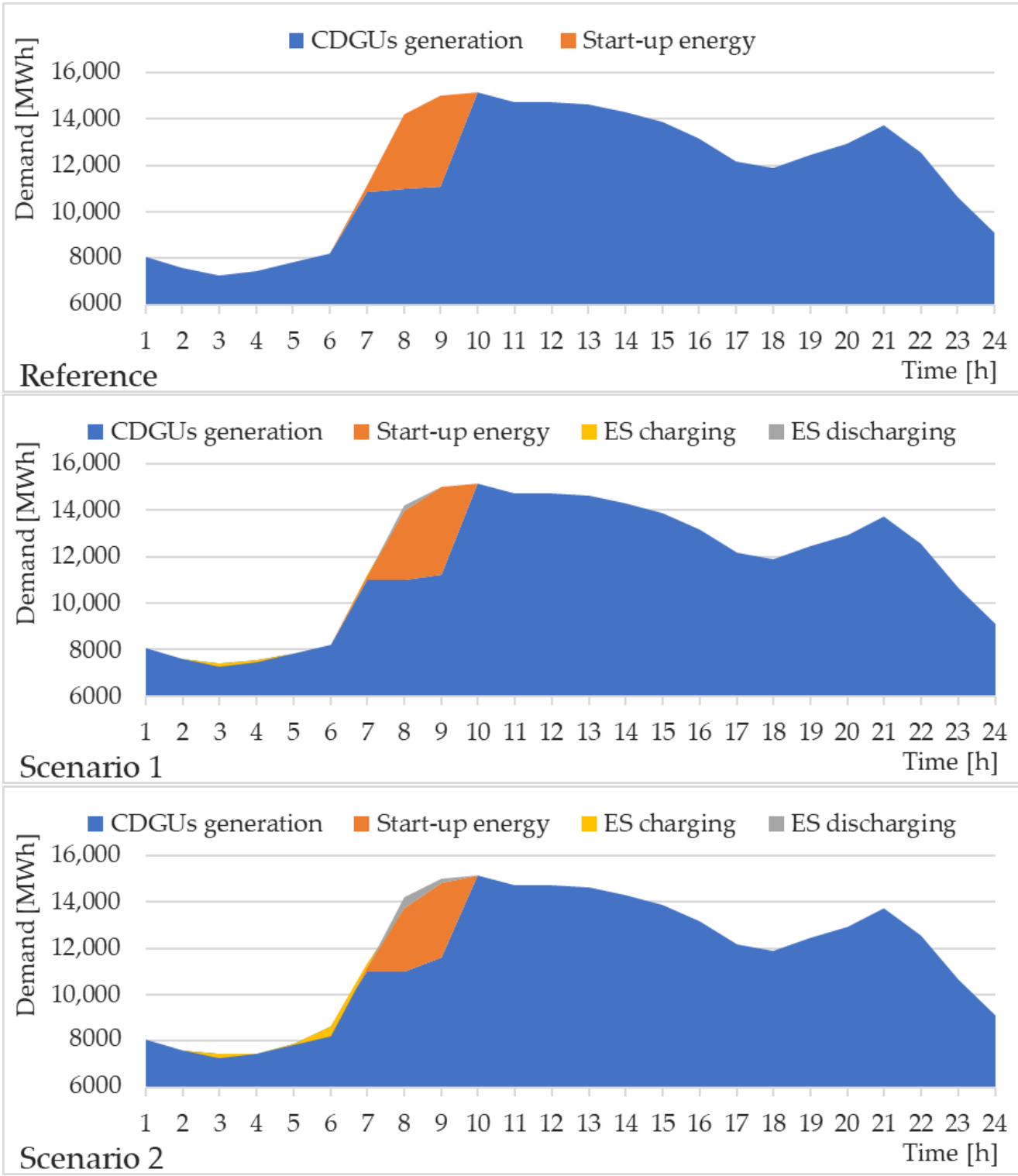

Figure 7. Cont. 


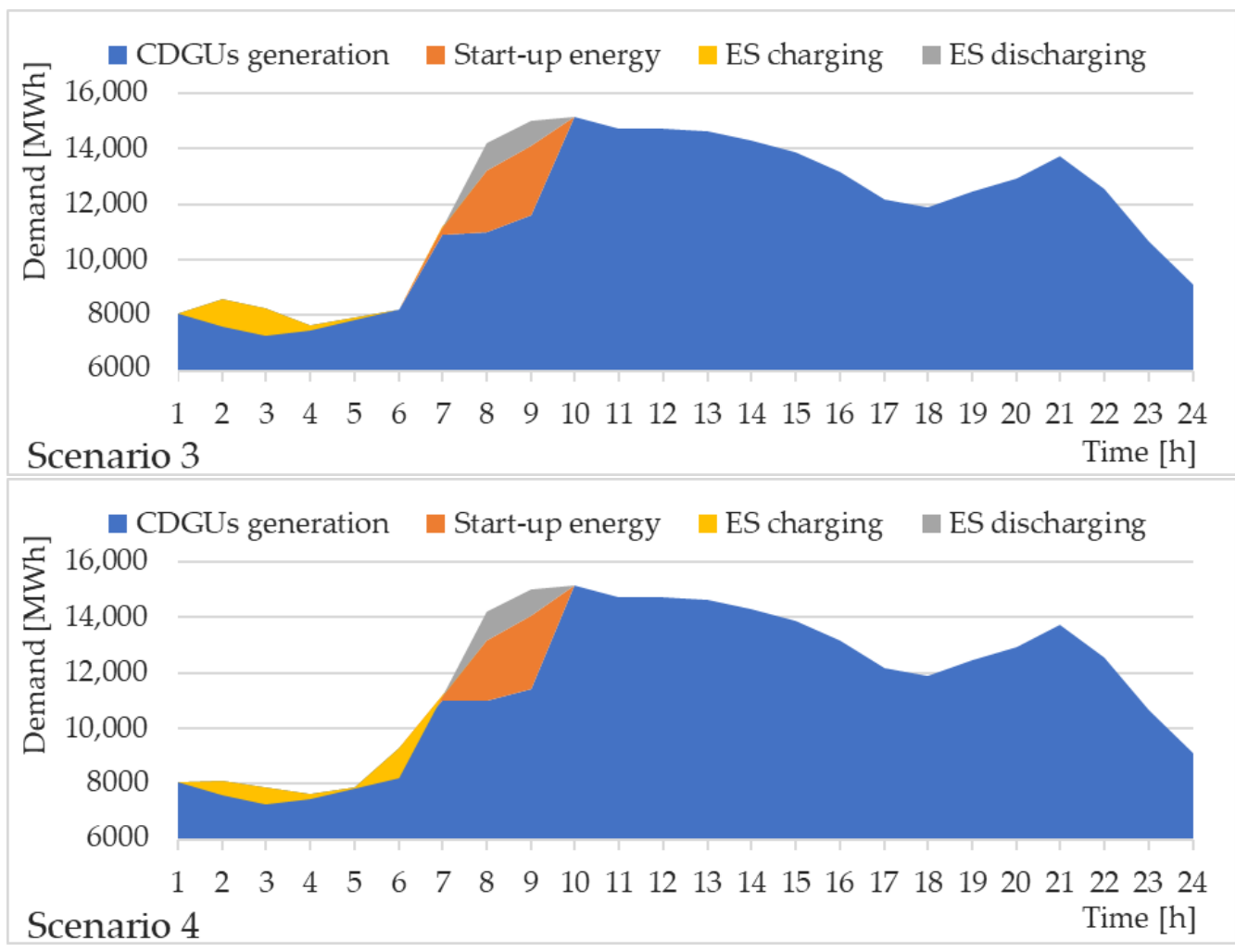

Figure 7. Results—distribution of generation, start-up energy, and energy storage (ES) operation.

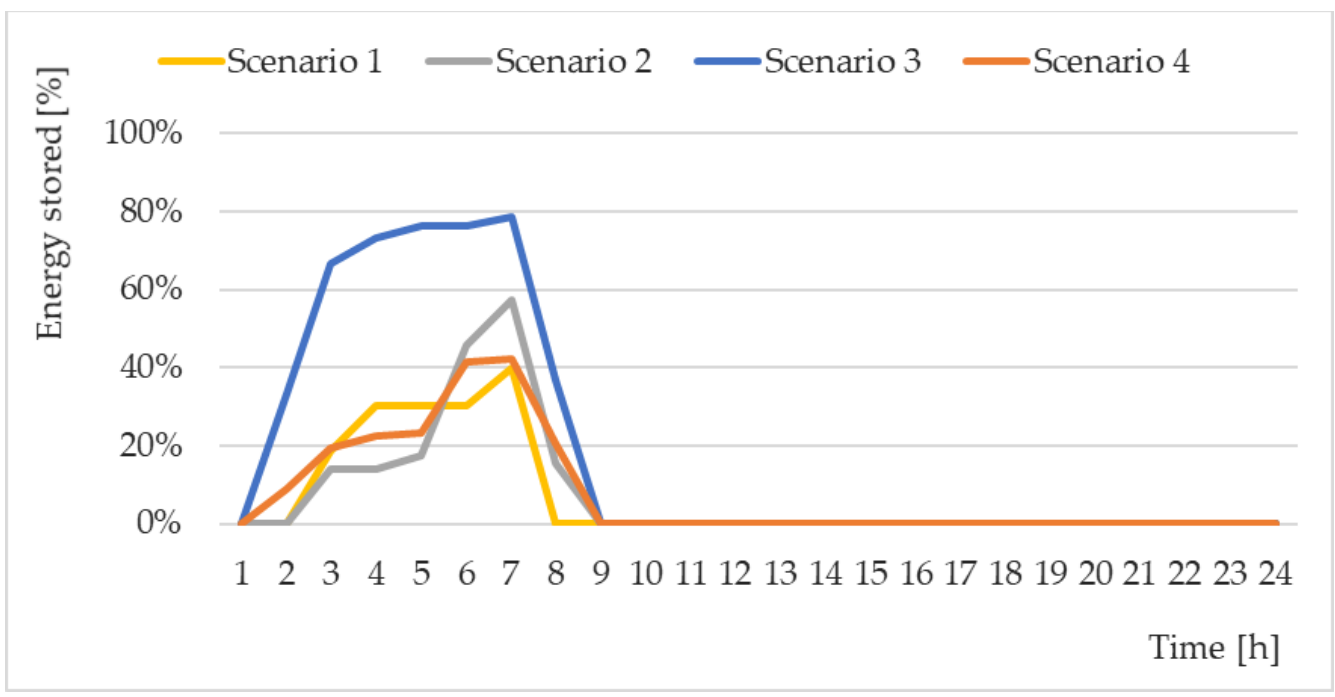

Figure 8. Results-energy stored in the energy storage (ES) depending on the simulation scenario.

The reference scenario assumes the operation of the modeled power system without the ES influence. The energy injected by the CDGUs during start-ups is additionally highlighted. Scenarios 1-4 assume the use of the ES in different shares according to the data presented in Table 2.

The fast-growing demand (especially during the morning ramp) has to be covered by additional CDGUs committed into production as already committed units are not able to respond to such rapid changes. The results show that ES discharging replaces expensive start-up energy and can reduce the number of CDGUs necessary to cover the daily demand. The amount of start-up energy is subsequently limited by the growing share of ES. The ES discharging takes place only during the periods of CDGU start-ups and does not occur in 
the remaining periods, even during peaks of demand, because high costs do not allow ES to compete with other generating units.

Figure 8 shows the utilization of the ES expressed as a percentage relation between energy stored and full available capacity and indicates that ES capacity is not fully utilized in all scenarios. The best results were obtained in Scenario 3 where ES capacity was exploited at $80 \%$. Lower ES parameters and their further increase resulted in significantly lower utilization. This indicates that the parameters of ES should be properly sized. The ES capacity may not be fully utilized and thus cause a lack of profitability for undersized and oversized installations. The problem is especially visible in the case of oversized ES- the power system can absorb a certain capacity and its excess remains idle.

The number of start-ups for the main simulations is presented in Figure 9.

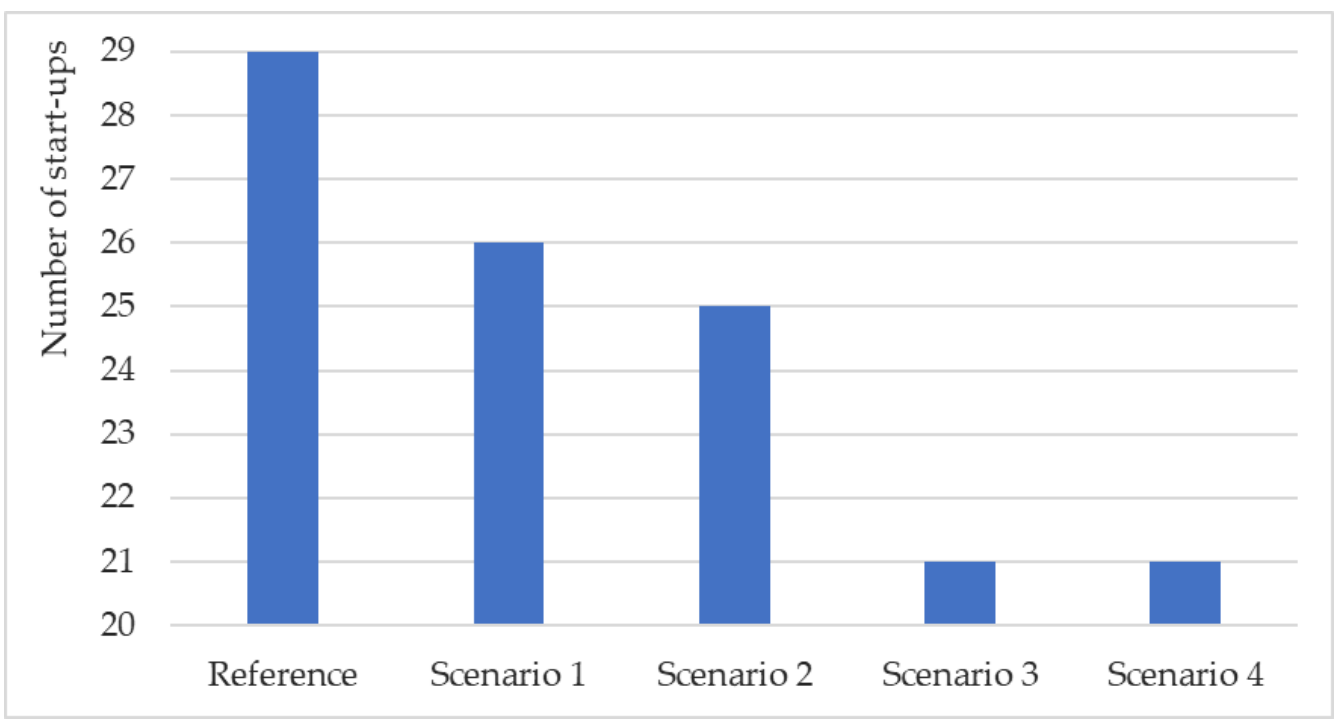

Figure 9. The number of start-ups for main simulations.

The growing share of ES in the modeled power system resulted in a lower number of CDGU start-ups. This positive effect can facilitate load-generation balancing as fixed start-ups are limited and more regulation abilities can be controlled by the power system operator. However, after exceeding the ES share of $1000 \mathrm{MW}$ and $3000 \mathrm{MWh}$, further reduction of start-ups does not occur-a certain number of CDGUs is required to maintain the operation of the power system after total discharging of ES capabilities. It should be also noticed that the first significant reduction of the CDGU start-ups required only $250 \mathrm{MW} / 750 \mathrm{MWh}$ ES capabilities (Scenario 1 with three fewer start-ups comparing to the reference scenario) while the subsequent significant reduction occurs with four-times more ES capabilities (Scenario 3 with 1000 MW /3000 MWh ES and five fewer start-ups comparing to the Scenario 1).

Scenarios 1-4 assumed four examples of ES characterized by the power to capacity ratio equal to $1 / 3$. Additional simulations analyse the impact of different range of ES rated parameters (in terms of power and capacity) on the number of CDGU start-ups to verify if other power to capacity ratios may have a greater impact on the analysed problem. The results are presented in Figure 10. 


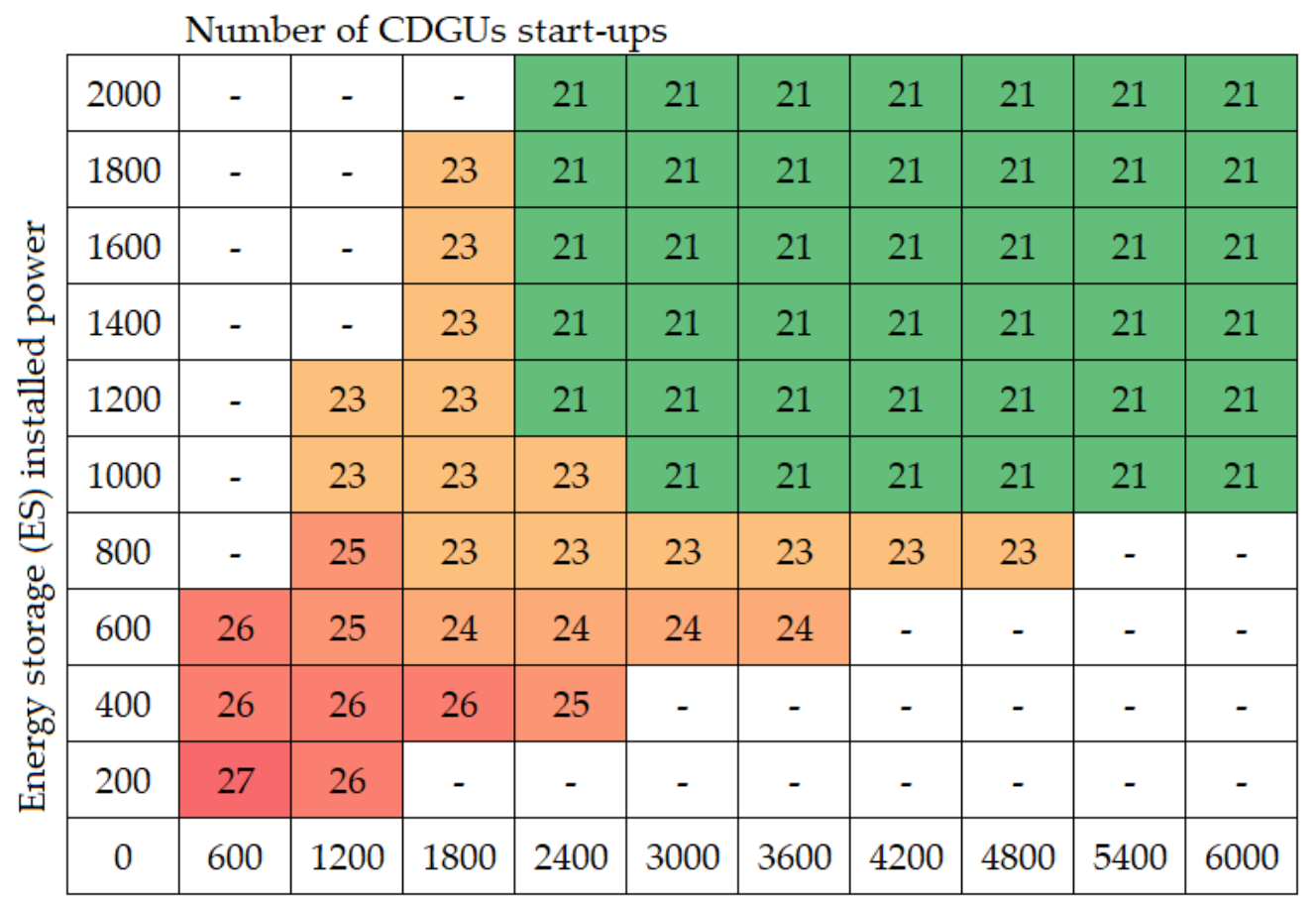

Energy storage (ES) installed capacity

Figure 10. Impact of energy storage (ES) rated parameters on the number of CDGUs start-ups.

The above-presented results take into account ES with a power to capacity ratio bigger than $1 / 6$ and smaller than 1.

It can be seen that increasing ES capacity has a minor impact on the number of startups, especially in cases of large ES (for example in the case of ES with power equal to $1800 \mathrm{MW}$ and $2000 \mathrm{MW}$ ). It may indicate that the high cost of ES operation constitutes a barrier for further reduction of CDGU start-ups because ES is not able to exploit the whole available capacity. The strongly reduced capacity results in the greater number of CDGU start-ups which is visible for small ES.

The last additional simulation presents the operation of the modeled power system assuming a significantly lower cost of ES operation. The cost is assumed to be lower than the costs of the most expensive peak power generating units $(75 \%$ of the peak-load generating costs). The $2000 \mathrm{MW} / 6000 \mathrm{MWh}$ ES was taken into consideration. The results are presented in Figures 11 and 12.

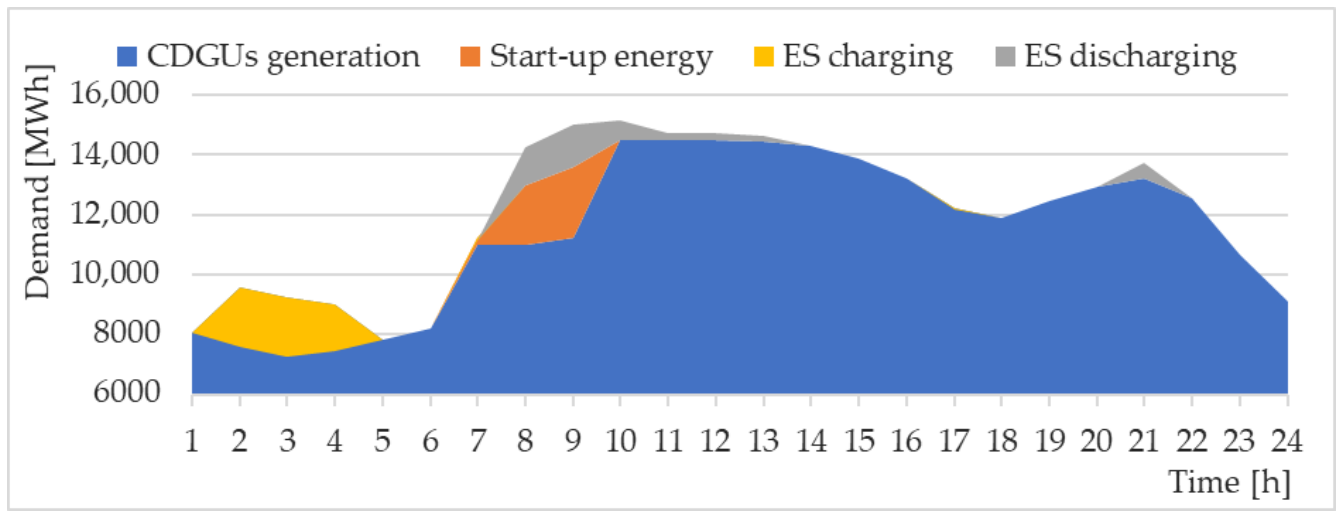

Figure 11. Results of the additional simulation—operation of the modeled system assuming lower costs of energy storage (ES). 


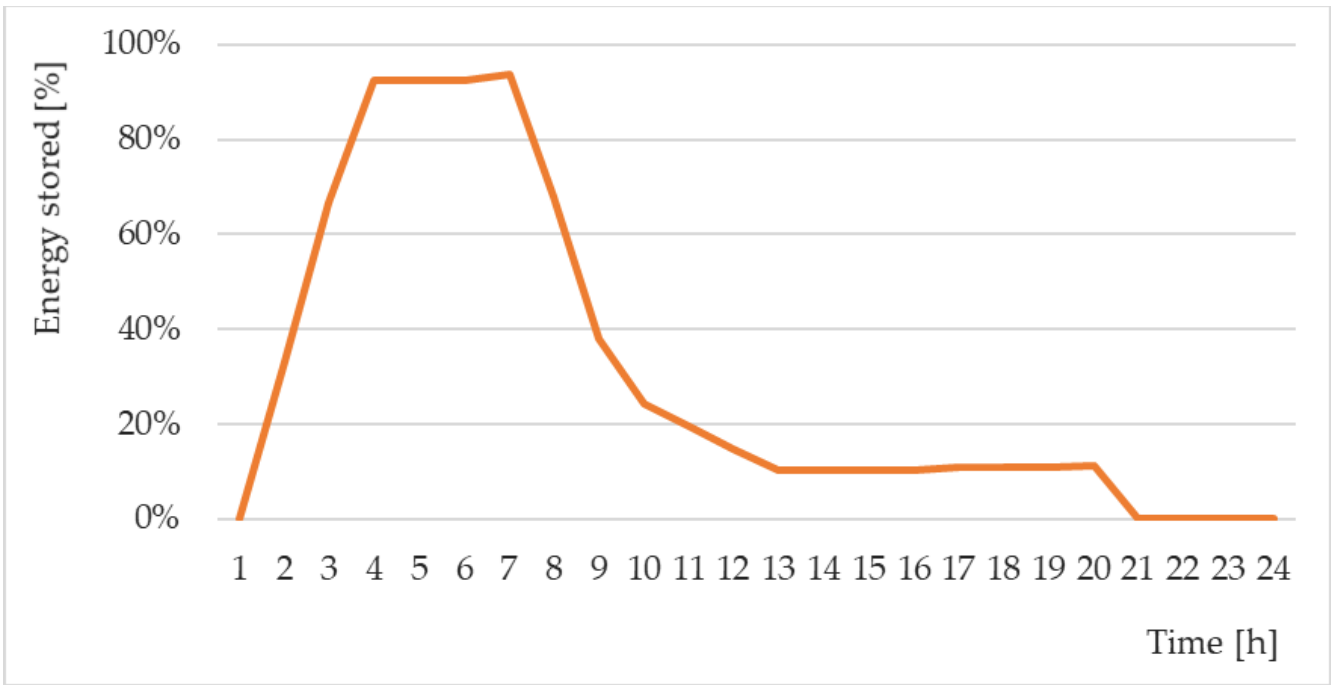

Figure 12. Results of the additional simulation—energy stored in the energy storage (ES) assuming lower costs of ES.

The lower costs of ES allow for their peak shaving operation and, as a result, the further reduction of CDGU start-ups as demand to be covered by CDGUs is lower. The discharging takes place also during the afternoon and the evening peaks. The ES capacity in this case is better utilized and used to more than $90 \%$. For the presented simulation, number of start-ups is equal to 19 and is smaller by 3 when comparing to the best results obtained in Scenarios 3 and 4 (Figure 13).

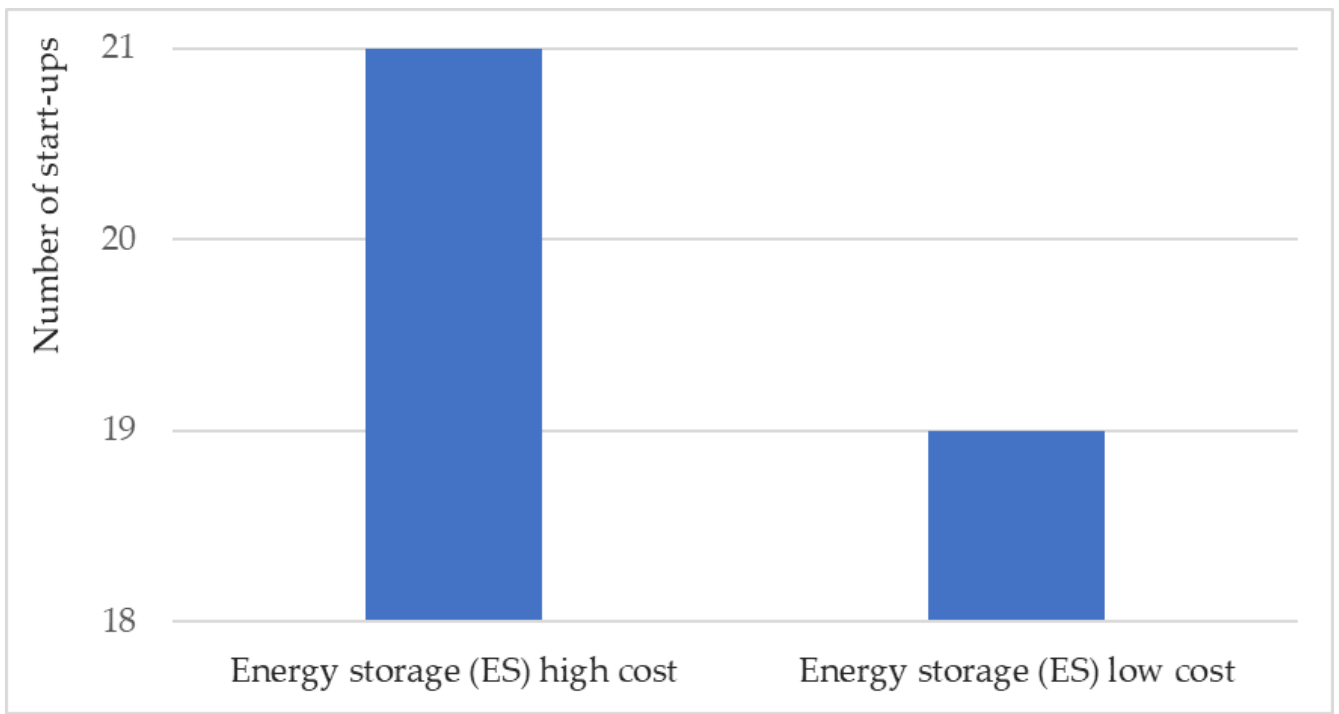

Figure 13. The biggest possible reductions of start-ups in the modeled system taking into account the different costs of ES operation.

The subsequent reduction of the number of CDGUs necessary to cover the daily electricity demand may bring additional benefits related to fulfillment of the provisions included in climate and energy policies. Nowadays, generation from conventional units such as fossil and gas power plants is burdened with additional costs related to i.e., European Union Emissions Trading System (EU ETS) [39] and provisions imposed by the Clean Energy for All Europeans Package issued by the European Commission [40]. It should be noted that in many power systems conventional generation represents a majority of the centrally dispatched assets able to provide load-generation balancing services to the power system operators, and their limitation may bring additional advantages. The 
impact of the proposed use of large-scale ES on the fulfillment of the provisions given by the climate and energy policies should be therefore analysed in further research.

\section{Conclusions}

The article presents the use of large-scale energy storage (ES) for the provision of load-generation balancing services allowing for the reduction of the number of centrally dispatched generating units (CDGUs) necessary to cover the daily electricity demand. The analysis based on the mixed-integer linear programming (MILP) optimization model and different simulation scenarios show the advantages of the proposed solution and identify barriers that should be faced to increase the proposed use of ES.

The reduction of CDGU start-ups results in more regulation abilities in periods of growing demand and therefore causes an increase in the power system's operation security and consequently may allow for a better adaptation of variable generation such as renewables. Further advantages cover the limitation of more expensive peak power generating units to be committed into production and the limitation of additional spending related to expensive start-up processes.

Nevertheless, the scope of the proposed service is limited due to the high costs of ES operation. The increased share of ES in the modeled system, both in terms of rated power as well as rated capacity, does not improve the scope of the service. The performed simulations also showed that subsequent significant reductions of the CDGU start-ups require several times more ES capabilities.

The parameters of ES should be properly sized. The ES capacity may not be fully utilized and thus cause a lack of profitability for undersized and oversized installations.

The further limitation of CDGU start-ups will be followed by a decrease in ES overall costs, which may occur shortly. This will also bring better utilization of the available ES rated parameters.

The subsequent benefits and precise impact of the proposed solutions on the implementation of the requirements given by the climate and energy policies should be analysed in further research. In particular, the European Union Emissions Trading System (EU ETS) and provisions imposed by the Clean Energy for all Europeans Package should be analysed. The cost-benefit analysis of the presented problem involving long-duration profiles (for a month, season or year) should be also performed to identify required earnings and the profitability of this ES application. In addition, the identification of the appropriate rated parameters of the ES providing the proposed service may be a challenge.

Author Contributions: D.C. and A.L. contributed equally to this work and all of its stages and elements. All authors have read and agreed to the published version of the manuscript.

Funding: This research received no external funding.

Acknowledgments: The authors would like to thank Professor Władysław Mielczarski (Institute of Electrical Power Engineering, Lodz University of Technology) for helpful suggestions and discussions which improve and strengthen the quality of this article. The authors would also like to express the gratitude to the $\mathrm{FICO}^{\circledR}$ corporation for programming support and the provision of academic licenses for Xpress Optimization Suite to the Institute of Electrical Power Engineering at the Lodz University of Technology.

Conflicts of Interest: The authors declare no conflict of interest.

\section{References}

1. Salles, M.B.C.; Huang, J.; Aziz, M.J.; Hogan, W.W. Potential Arbitrage Revenue of Energy Storage Systems in PJM. Energies 2017, 10, 1100. [CrossRef]

2. Pavić, I.; Luburić, Z.; Pandžić, H.; Capuder, T.; Androcec, I. Defining and Evaluating Use Cases for Battery Energy Storage Investments: Case Study in Croatia. Energies 2019, 12, 376. [CrossRef]

3. Fan, X.; Liu, B.; Liu, J.; Ding, J.; Han, X.; Deng, Y.; Lv, X.; Xie, Y.; Chen, B.; Hu, W.; et al. Battery Technologies for Grid-Level Large-Scale Electrical Energy Storage. Trans. Tianjin Univ. 2020, 26, 92-103. [CrossRef] 
4. Chen, T.; Jin, Y.; Lv, H.; Yang, A.; Liu, M.; Chen, B.; Xie, Y.; Chen, Q. Applications of Lithium-Ion Batteries in Grid-Scale Energy Storage Systems. Trans. Tianjin Univ. 2020, 26, 208-217. [CrossRef]

5. Flegkas, S.; Birkelbach, F.; Winter, F.; Groenewold, H.; Werner, A. Profitability Analysis and Capital Cost Estimation of a Thermochemical Energy Storage System Utilizing Fluidized Bed Reactors and the Reaction System $\mathrm{MgO} / \mathrm{Mg}(\mathrm{OH})_{2}$. Energies 2019, 12, 4788. [CrossRef]

6. International Renewable Energy Agency (IRENA). Electricity Storage and Renewables: Costs and Markets to 2030. October 2017. Available online: https://www.irena.org/-/media/Files/IRENA/Agency/Publication/2017/Oct/IRENA_Electricity_Storage_ Costs_2017_Summary.pdf?la=en\&hash=2FDC44939920F8D2BA29CB762C607BC9E882D4E9 (accessed on 12 November 2020).

7. Mongird, K.; Viswanathan, V.; Balducci, P.; Alam, J.; Fotedar, V.; Koritarov, V.; Hadjerioua, B. An Evaluation of En-ergy Storage Cost and Performance Characteristics. Energies 2020, 13, 3307. [CrossRef]

8. Cole, W.; Frazier, W. Cost Projections for Utility-Scale Battery Storage. National Renewable Energy Laboratory (NREL), June 2019. Available online: https:/ / www.nrel.gov/docs/fy19osti/73222.pdf (accessed on 10 November 2020).

9. Hossain, E.; Faruque, H.M.R.; Sunny, M.S.H.; Mohammad, N.; Nawar, N. A Comprehensive Review on Energy Stor-age Systems: Types, Comparison, Current Scenario, Applications, Barriers, and Potential Solution, Policies, and Future Prospects. Energies 2020, 13, 3651. [CrossRef]

10. Xu, X.; Bishop, M.; Oikarinen, D.G.; Hao, C. Application and modeling of battery energy storage in power system. CSEE J. Power Energy Syst. 2016, 2, 82-90. [CrossRef]

11. Reihani, E.; Sepasi, S.; Roose, L.R.; Matsuura, M. Energy management at the distribution grid using a Battery Energy Storage System (BESS). Int. J. Electr. Power Energy Syst. 2016, 77, 337-344. [CrossRef]

12. Pandya, M.H.; Aware, M.V. Enhancing the distribution feeder capacity through energy storage. In Proceedings of the 2013 IEEE International Conference on Industrial Technology (ICIT), Cape Town, South Africa, 25-28 February 2013; pp. 1739-1744. [CrossRef]

13. Ke, X.; Lu, N.; Jin, C. Control and size energy storage for managing energy balance of variable generation resources. In Proceedings of the 2014 IEEE PES General Meeting I Conference \& Exposition, National Harbor, MD, USA, $27-31$ July 2014.

14. Hayes, B.; Wilson, A.; Webster, R.; Djokic, S.Z. Comparison of two energy storage options for optimum balancing of wind farm power outputs. IET Gener. Transm. Distrib. 2016, 10, 832-839. [CrossRef]

15. Gusev, Y.P.; Subbotin, P.V. Using Battery Energy Storage Systems for Load Balancing and Reactive Power Compensa-tion in Distribution Grids. In Proceedings of the International Conference on Industrial Engineering, Applications and Manufacturing (ICIEAM), Sochi, Russia, 25-29 March 2019.

16. Duerr, S.; Ababei, C.; Ionel, D.M. A Case for Using Distributed Energy Storage for Load Balancing and Power Loss Minimization in Distribution Networks. Electr. Power Compon. Syst. 2020, 48, 1-14. [CrossRef]

17. Faessler, B.; Schuler, M.; Preißinger, M.; Kepplinger, P. Battery Storage Systems as Grid-Balancing Measure in Low-Voltage Distribution Grids with Distributed Generation. Energies 2017, 10, 2161. [CrossRef]

18. Duerr, S.; Ababei, C.; Ionel, D.M. Load balancing with energy storage systems based on co-simulation of multiple smart buildings and distribution networks. In Proceedings of the 2017 IEEE 6th International Conference on Renewable Energy Research and Applications (ICRERA), San Diego, CA, USA, 5-8 November 2017; pp. 175-180.

19. Zhang, S.; Tang, Y. Optimal schedule of grid-connected residential PV generation systems with battery storages under time-of-use and step tariffs. J. Energy Storage 2019, 23, 175-182. [CrossRef]

20. Kahlen, M.T.; Ketter, W.; Van Dalen, J. Electric Vehicle Virtual Power Plant Dilemma: Grid Balancing Versus Customer Mobility. Prod. Oper. Manag. 2018, 27, 2054-2070. [CrossRef]

21. Clement-Nyns, K.; Haesen, E.; Driesen, J. The impact of vehicle-to-grid on the distribution grid. Electr. Power Syst. Res. 2011, 81, 185-192. [CrossRef]

22. Reid, G.; Julve, J. Second Life-Batteries as Flexible Storage For Renewables Energies. Bundesverband Erneuerbare Energie E.V. (BEE), April 2016. Available online: https:/ / www.bee-ev.de/fileadmin/Publikationen/Studien/201604_Second_Life-Batterien_ als_flexible_Speicher.pdf (accessed on 6 April 2021).

23. Mielczarski, W. Impact of Energy Storage on Load Balancing. In Proceedings of the 201815 th International Conference on the European Energy Market (EEM), Lodz, Poland, 27-29 June 2018; pp. 1-5.

24. Mielczarski, W. Handbook: Energy Systems \& Markets, Edition I-June 2018. Available online: http:/ / www.eem18.eu/gfx/eemnetwork/userfiles/_public/handbook_energy_systems__markets.pdf (accessed on 16 November 2020).

25. Polish Power System Operator-PSE S.A. Polish Power System Operation—Load of Polish Power System. Available online: https:/ / www.pse.pl/web/pse-eng/areas-of-activity/polish-power-system/system-load (accessed on 16 November 2020).

26. Polish Power System Operator-PSE S.A. Instruction of Transmission System Operation and Maintenance. Balancing and Congestion Management. Available online: https://www.pse.pl/documents/20182/304683674/IRiESP-Bilansowanie_v1_0 _tekst_jednolity_po_KA_CB_19_2018_od_29_10_2018.pdf (accessed on 18 November 2020).

27. Kasprzyk, S.; Mielczarski, W. Modern Commitment and Dispatch in the Balancing Market. From the Volume "Devel-opment of Electricity Markets", Edition “The European Power Supply Industry", Technical University of Lodz, April 2005. Available online: https: / www.researchgate.net/publication/315833613_Modern_Commitment_and_Dispatch_in_Balancing_Markets (accessed on 18 November 2020). 
28. Chudy, D. Energy Storage Systems for Commitment and Dispatch of Conventional Power Plants. In Proceedings of the 2018 15th International Conference on the European Energy Market (EEM), Lodz, Poland, 27-29 June 2018; pp. 1-5.

29. Chowdhury, J.I.; Balta-Ozkan, N.; Goglio, P.; Hu, Y.; Varga, L.; McCabe, L. Techno-environmental analysis of battery storage for grid level energy services. Renew. Sustain. Energy Rev. 2020, 131, 110018. [CrossRef]

30. Nyamdash, B.; Denny, E.; O'Malley, M. The viability of balancing wind generation with large scale energy storage. Energy Policy 2010, 38, 7200-7208. [CrossRef]

31. Dzikowski, R. DSO-TSO Coordination of Day-Ahead Operation Planning with the Use of Distributed Energy Re-sources. Energies 2020, 13, 3559. [CrossRef]

32. Ostrowski, J.; Anjos, M.F.; Vannelli, A. Tight Mixed Integer Linear Programming Formulations for the Unit Commitment Problem. IEEE Trans. Power Syst. 2012, 27, 39-46. [CrossRef]

33. Carrion, M.; Arroyo, J.M. A computationally efficient mixed-integer linear formulation for the thermal unit commit-ment problem. IEEE Trans. Power Syst. 2006, 21, 1371-1378. [CrossRef]

34. Hemmati, R.; Saboori, H. Short-term bulk energy storage system scheduling for load leveling in unit commitment: Modeling, optimization, and sensitivity analysis. J. Adv. Res. 2016, 7, 360-372. [CrossRef] [PubMed]

35. Lesniak, A.; Chudy, D.; Dzikowski, R. Modelling of Distributed Resource Aggregation for the Provision of Ancillary Services. Energies 2020, 13, 4598. [CrossRef]

36. Polish Power System Operator-PSE S.A. Polish Power System Operation-Day Ahead Coordinated Plan-Basic Data. Available online: https://www.pse.pl/web/pse-eng/data/polish-power-system-operation/intra-day-basic-data (accessed on 20 November 2020).

37. Lazard. Lazard's Levelized Cost of Energy Analysis-Version 14.0. October 2020. Available online: https://www.lazard.com/ media/451419/lazards-levelized-cost-of-energy-version-140.pdf (accessed on 12 December 2020).

38. Lazard. Lazard's Levelized Cost of Storage Analysis-Version 6.0. October 2020. Available online: https://www.lazard.com/ media/451418/lazards-levelized-cost-of-storage-version-60.pdf (accessed on 12 December 2020).

39. Official Journal of the European Union. Directive 2003/87/EC of the European Parliament and of the Council of 13 October 2003 Establishing a Scheme for Greenhouse Gas Emission Allowance Trading within the Community and Amending Council Directive 96/61/EC. Available online: https:/ / eur-lex.europa.eu/legal-content/EN/TXT/PDF/?uri=CELEX:32003L0087\&from= EN (accessed on 20 November 2020).

40. Official Journal of the European Union. Regulation (EU) 2019/943 of the European Parliament and of the Council of 5 June 2019 on the Internal Market for Electricity. Available online: https:/ / eur-lex.europa.eu/legal-content/EN/TXT/PDF/?uri=CELEX: 32019R0943\&rid=1 (accessed on 20 November 2020). 